ISSN 1678-3921

Journal homepage: www.embrapa.br/pab

For manuscript submission and journal contents, access: www.scielo.br/pab

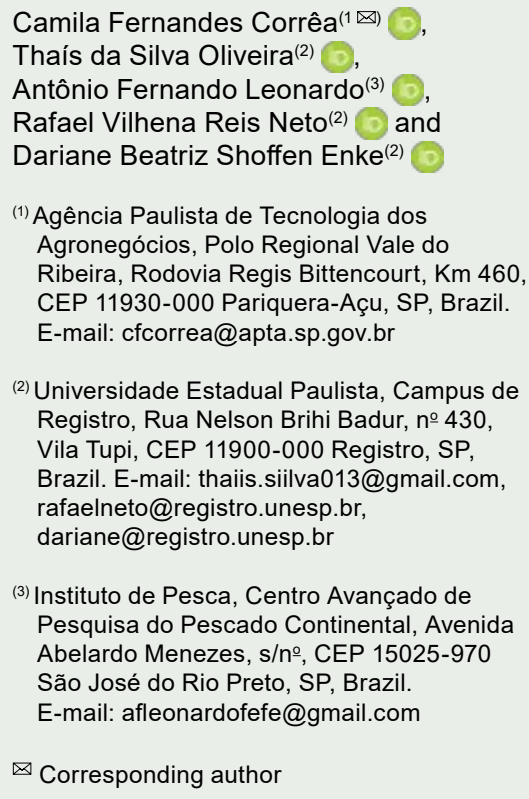

(2) Universidade Estadual Paulista, Campus de Registro, Rua Nelson Brihi Badur, № 430, Vila Tupi, CEP 11900-000 Registro, SP, Brazil. E-mail: thaiis.siilva013@gmail.com, rafaelneto@registro.unesp.br, dariane@registro.unesp.br

(3) Instituto de Pesca, Centro Avançado de Pesquisa do Pescado Continental, Avenida Abelardo Menezes, s/no, CEP 15025-970 São José do Rio Preto, SP, Brazil. E-mail: afleonardofefe@gmail.com

$\bowtie$ Corresponding author

Received

October 1, 2019

Accepted

March 3, 2020

How to cite

CORREA, C.F.; OLIVEIRA, T. da S.

LEONARDO A.F.; REIS NETO, R.V.; ENKE D.B.S. Acid fish silage in the diet of pacu and tambacu reared at cold suboptimal temperature. Pesquisa Agropecuária Brasileira, v.55, e01653, 2020. DOI: https://doi.org/10.1590/ S1678-3921.pab2020.v55.01653.

\section{Acid fish silage in the diet of pacu and tambacu reared at cold suboptimal temperature}

\begin{abstract}
The objective of this work was to evaluate the supplementation of diet of pacu and tambacu with acid fish silage during winter. The experimental design was a $2 \times 2$ factorial arrangement (two genetic groups and two diets), with three replicates. The genetic group factor was composed of pacu (Piaractus mesopotamicus) and tambacu (q Colossoma macropomum $\times \hat{\sigma}$ Piaractus mesopotamicus). The two diets were based on plant ingredients; one of them was supplemented with acid fish silage (silage diet), and the other was a base diet without supplementation. Twelve net tanks, six from which with pacu, and six with tambacu, were used as experimental units, with ten fish in each tank. There was an interaction of the factors for final length, final weight, and daily weight gain. Pacu fed the silage diet showed a higher growth than pacu fed with the base diet; however, this effect was not observed for tambacu. A higher feed efficiency was observed for pacu than for tambacu, without a diet effect. The diet supplementation with acid fish silage improves the productive performance of pacu reared at cold suboptimal temperature, but it does not have this effect on tambacu.
\end{abstract}

Index terms: Piaractus mesopotamicus, Colossoma macropomum $\times$ Piaractus mesopotamicus, growth, protein, winter.

\section{Silagem ácida de peixe na dieta de pacu e tambacu criados à temperatura subótima fria}

Resumo-O objetivo deste trabalho foi avaliar a suplementação da dieta de pacu e tambacu com silagem ácida de pescado durante o inverno. O delineamento experimental foi feito em arranjo fatorial $2 \times 2$ (dois grupos genéticos e duas dietas), com três repetições. O fator grupos genéticos foi composto pelo pacu (Piaractus mesopotamicus) e pelo tambacu ( $\&$ Colossoma macropomum $\times$ $\hat{\sigma}$ Piaractus mesopotamicus). As duas dietas foram compostas com base em ingredientes vegetais; uma delas foi suplementada com silagem ácida de pescado (dieta silagem), e a outra foi uma dieta base sem suplementação. Doze tanques-rede, seis deles com pacu e seis com tambacu, foram utilizados como unidades experimentais, com dez peixes em cada um. Houve interação entre os fatores quanto ao comprimento final, massa final e ganho diário de massa. O pacu alimentado com a dieta silagem apresentou maior crescimento do que o pacu alimentado com a dieta base; no entanto, este efeito não foi observado no tambacu. Observou-se eficiência alimentar maior no pacu do que no tambacu, sem efeito das dietas. A suplementação da dieta com silagem ácida de pescado melhora o desempenho produtivo do pacu criado em temperatura subótima fria, mas não tem este efeito sobre o tambacu.

Termos para indexação: Piaractus mesopotamicus, Colossoma macropomum × Piaractus mesopotamicus, crescimento, proteína, inverno. 


\section{Introduction}

World aquaculture grows at an accelerated rate and has already surpassed fisheries as the main protein source for human consumption (FAO, 2018). Much of aquaculture development occurs in subtropical climate, where large temperature differences occur between summer and winter. It is critical to the success of the activity to find adapted species to environment conditions, and diets to help these animals overcome climate challenge.

Round fish (species and hybrids of the genera Colossoma and Piaractus) is one of the most produced fish group in Brazil, after only tilapia production. While in the northern and central-western Brazil the main species of round fish raised is tambaqui (Colossoma macropomum) (IBGE, 2016), in the southern Brazil the main produced species are pacu (Piaractus mesopotamicus) and the hybrid tambacu ( $q$ Colossoma macropomum $\times$ ठ Piaractus mesopotamicus). The hybrid combines desirable characteristics of both originating species: greater growth rate of tambaqui in tropical climate, and a better adaptation of pacu to temperature oscillation in subtropical climate. Fernandes et al. (2018) compared the survival of pure breeds and hybrids of pacu and tambacu during winter, and verified a higher tolerance of pacu, followed by the hybrid tambacu, than that of tambaqui and the hybrid paqui. However, for a genetic group to express its full potential in growth, it needs an adequate nutrition and specific rearing conditions.

The diet is responsible for the main part of fish farming, and protein ingredients are the ones that most contribute to this cost (Pezzato et al., 2009). Fishmeal has a great quality as protein ingredient in fish feeds, but because of the stagnation of fisheries and demand growth by aquaculture, there was a drastic reduction in its use (FAO, 2018). Soybean meal is a good protein plant ingredient, but the presence of some antinutrients should be considered. However, the supplementation of plant diets with alternative ingredients of animal origin can bring benefits. El-Sayed (1999) observed that mixing soybean meal with a protein of animal origin increases its quality for tilapia, and that fish silage has a good potential as a protein source. Also, Banze et al. (2017) studied acid fish silage as a fishmeal substitute in the diet of South American catfish (jundiá in Portuguese), Rhamdia quelen, and concluded that the silage is a good alternative protein source in aquafeeds.

Acid silage is an effective way to preserve fish slaughter residue, when the volume is not large enough to enable the production of fish meal and fish oil (Olsen $\&$ Toppe, 2017). According to these authors, acid fish silage not only preserves nutrients for use in animal feeding, but it can also be used as a food additive with growth promoting properties.

Studies comparing the productivity performance of pacu and tambacu are scarce, particularly at cold suboptimal temperature. Also, studies on the supplementation of acid fish silage for these fish were not found in the literature.

The objective of this work was to evaluate the supplementation of diet of pacu and tambacu with acid fish silage, during winter, at cold suboptimal temperature.

\section{Materials and Methods}

The study was carried out at the experimental fish farming of Polo Regional Vale do Ribeira of Agência Paulista de Tecnologia dos Agronegócios (APTA), at $24^{\circ} 43^{\prime} 14^{\prime \prime} \mathrm{S}, 4^{\circ} 52^{\prime} 43^{\prime \prime} \mathrm{W}$, in Pariquera-Açu county, in the state of São Paulo, Brazil, during the winter at subtropical climate.

The experiment was conducted in a completely randomized design, in a $2 \times 2$ factorial arrangement (two genetic groups and two diets), totalizing four treatments, with three replicates. The genetic group was composed of juveniles of pacu (Piaractus mesopotamicus) and tambacu (q Colossoma macropomum $\times \hat{\sigma}$ Piaractus mesopotamicus). The diets were based on plant ingredients, and one of them was supplemented with acid fish silage (silage diet), and the other was a base diet without supplementation.

The diets were made with soybean meal, as the main protein ingredient, and wheat meal as the main energy ingredient. Only in the silage diet, soybean meal was partially replaced with acid fish silage. In addition, adjustments were made in the sources of lipids and minerals, as the silage was richer in these nutrients than the soybean meal (Table 1).

The acid fish silage was obtained from residue of fish processing, collected in fish markets in Vale do Ribeira region. The residue was composed mainly of viscera, heads, and spinal columns with some 
remaining muscles of fish from marine and fresh water origins. After the collection, the residue was processed in an electric meat grinder, packed in plastic containers added with commercial acetic acid $(10 \%$ weight $)$ and hydroxy-butyl-toluene $\left(0.2 \mathrm{~g} \mathrm{~kg}^{-1}\right)$. Manual mixing of the residue was performed during the first five days of the silage process, and hydrolysis occurred during 30 days at room temperature.

The diets were isoproteic and isoenergetic (Table 1), formulated to meet the requirements for pacu and tambacu, according to the recommendations of Bicudo et al. (2012) and Oliveira et al. (2012). The ingredients were manually mixed, adjusted for moisture, pelletized in an adapted electric meat grinder, and oven-dried at $55^{\circ} \mathrm{C}$. Obtained pellets were $4.17 \pm 0.16 \mathrm{~mm}$ diameter (mean \pm standard deviation) and $7.83 \pm 2.43 \mathrm{~mm}$ length. The experimental ingredients and diets were analyzed for protein, lipid, ash, and moisture, according to the methods described by AOAC (1999).

Initial total length and weight (mean \pm standard deviation) of juveniles were, respectively: $10.39 \pm 1.01$ $\mathrm{cm}$ and $18.97 \pm 5.50 \mathrm{~g}$, for pacu; and $11.07 \pm 0.77 \mathrm{~cm}$ and $21.68 \pm 4.45 \mathrm{~g}$ for tambacu. The experimental units

Table 1. Experimental diet composition ( $\mathrm{g} \mathrm{kg}^{-1}$ dry weight).

\begin{tabular}{lcc}
\hline Ingredients & Base diet & Silage diet \\
\hline Soybean meal & 449.5 & 405.0 \\
Wheat meal & 381.9 & 397.5 \\
Wheat flour & 100.0 & 100.0 \\
Acid fish silage ${ }^{(1)}$ & - & 50.0 \\
Canola oil & 33.4 & 17.3 \\
Vitamin and mineral mix & 5.0 & 5.0 \\
Dicalcium phosphate & 30.0 & 25.0 \\
Butyl hydroxy toluene $(\mathrm{BHT})$ & 0.2 & 0.2 \\
\hline Composition & & \\
Dry matter & 923.2 & 912.9 \\
Protein & 320.2 & 318.7 \\
Lipid & 71.9 & 79.3 \\
Ash & 76.8 & 86.2 \\
Nitrogen-free extract & 530.5 & 515.7 \\
Energy $^{(3)}\left(\mathrm{MJ} \mathrm{kg}^{-1}\right)$ & 19.62 & 19.61 \\
\hline
\end{tabular}

${ }^{(1)}$ Composition ( $\mathrm{g} \mathrm{kg}^{-1}$ dry weight) of acid fish silage obtained from processing residue of fresh water and marine fish: dry matter, 355.0; protein, 309.5; lipid, 326.7; and ash, 171.8. ${ }^{(2)}$ Estimated by difference. ${ }^{(3)}$ Estimated considering 17.38, 23.66, and $39.66 \mathrm{MJ} \mathrm{kg}^{-1}$ for carbohydrate, protein, and lipid, respectively. were $1 \mathrm{~m}^{3}(1 \times 1 \times 1 \mathrm{~m})$ net cages with mesh opening of $3 \mathrm{~mm}$. The net cages were placed in a $600 \mathrm{~m}^{2}$ earth pond, with an average depth of $1.5 \mathrm{~m}$. Ten fish were stored per experimental unit, in a total of 12 net cages (6 with pacu, and 6 with tambacu). The experimental period was approximately six months (176 days), from May to November 2016.

During the entire experimental period, fish were fed at $2 \%$ of their mass per day, divided into two daily feeding (at 9:00 $\mathrm{h}$ and 15:00 h). Feeding quantities were adjusted after each biometry. To simulate a real breeding situation, fish were not fed on Sundays, on biometry days, and when pond water temperature was below $18^{\circ} \mathrm{C}$. During the 176 days of the experiment, fish received feed in 123 days.

To observe growth and readjust the feed, six biometries were performed at intervals of 30 or 60 days in 2016 (May 16, July 13, September 13, October 18, and November 08), depending on temperature conditions. In the initial and final biometries, total length and weight of individuals were recorded, and in the intermediary biometry, only weight was recorded. Two fish per experimental unit were sampled at the end of the study, for the evaluation of hepatosomatic and viscerosomatic indexes. In addition, at the end of study, 10 fish from initial batches and 3 fish per unit were sampled for body composition analyses: moisture, crude protein, lipid, and mineral matter, according to the methods described by AOAC (1999). Fish management was carried out according to the procedures approved by the committee on ethics in animal use (Comitê de Ética no Uso de Animais, CEUA) of the Universidade Estadual Paulista (Unesp), protocol 8.963/16.

Environment conditions were monitored in the water of the pond where experimental units were installed, according to Leonardo et al. (2011). Temperature was monitored daily, using a mercury thermometer of maximum and minimum. Every week, the following parameters were evaluated: dissolved oxygen, by a digital meter; transparency, using Secchi disc; total alkalinity, by titration; $\mathrm{pH}$, by a digital meter; and electrical conductivity, by a digital meter. And, every month, evaluations were performed for: total ammoniacal nitrogen; nitrite and nitrate; orthophosphate; and total phosphorus, by spectrophotometry. In the period of evaluation (May to November 2016), the highest recorded 
water temperature was $31^{\circ} \mathrm{C}$, and the lowest one was $14^{\circ} \mathrm{C}$. The means ( \pm standard deviation) of daily maximum and minimum temperatures were $22 \pm 3^{\circ} \mathrm{C}$ and $20 \pm 2^{\circ} \mathrm{C}$, respectively. The following values were obtained for the other parameters (mean \pm standard deviation): $5.8 \pm 0.6 \mathrm{mg} \mathrm{L}^{-1}$ dissolved oxygen; $60 \pm 0 \mathrm{~cm}$ transparency; $24.4 \pm 2.0 \mathrm{mg} \mathrm{L}^{-1} \mathrm{CaCO}_{3}$ total alkalinity; $5.8 \pm 0.4 \mathrm{pH} ; 44.3 \pm 1.6 \mu \mathrm{mS} \mathrm{cm}^{-1}$ electrical conductivity; $<0.001 \mathrm{mg} \mathrm{L}^{-1}$ total ammoniacal nitrogen; $0.065 \pm 0.030$ $\mathrm{mg} \mathrm{L}^{-1}$ nitrite; $<0.001 \mathrm{mg} \mathrm{L}^{-1}$ nitrate; $<0.001 \mathrm{mg} \mathrm{L}^{-1}$ orthophosphate; and $<0.001 \mathrm{mg} \mathrm{L}^{-1}$ total phosphorus.

With the obtained data, the following parameters of productive performance were calculated and analyzed: Survival $(\%)=($ final number $/$ initial number $) \times 100$; final weight $(\mathrm{g})$; final lenght $(\mathrm{cm})$; condition factor $(\mathrm{K})$ $=\left(\right.$ weight $/$ length $\left.{ }^{3}\right) \times 100$; daily weight gain $(\mathrm{DWG}-$ g per day) $=$ weight gain / days; feed efficiency $(\mathrm{FE})$ $=$ weight gain / feed intake; protein efficiency ratio $($ PER $)=$ weight gain / protein intake; apparent net protein utilization $($ ANPU $-\%)=($ body protein gain $/$ protein intake) $\times 100$; apparent net energy utilization $($ ANEU $-\%)=($ body energy gain / energy intake $) \times$ 100; viscerosomatic index $(\mathrm{VSI}-\%)=($ viscera weight $/$ body weight $\times 100$; hepatosomatic index (HSI $-\%)=($ liver weight $/$ body weight $) \times 100$; proximal composition, $\%$ of moisture, protein, lipid and ash.

Data were tested for the pre-assumptions and subjected to the analysis of variance, and comparison of means by Tukey's test, at $5 \%$ probability. There was loss of an experimental unit (one replicate of the "pacu $\times$ silage diet" treatment), considered as a lost plot in the statistical analysis.

\section{Results and Discussion}

There was interaction between the tested factors, genetic group and diet, for growth, considering final length, final weight, and daily weight gain (Table 2, Figure 1). Pacu fed the silage diet had higher growth than pacu fed the base diet, but for tambacu this effect was not observed. Moreover, pacu showed a better growth than tambacu only when fed the silage diet. Pacu that received the silage diet showed daily weight gain 33\% higher than pacu fed the base diet. Comparing the daily weight gain of the genetic groups that received the silage diet, the difference observed was even greater; this parameter in pacu was $56 \%$ higher than in tambacu.

Reis Neto et al. (2012) reported positive heterosis for weight gain of the hybrids obtained from tambaqui and pacu crosses; however, the evaluation was performed at optimum rearing temperature. In the present study, the origin of the genetic group was apparently decisive for fish adaptation to the subtropical winter. There was lower performance of the hybrid tambacu in relation to the pure breed pacu, but without occurrence

Table 2. Growth and food use of pacu (Piaractus mesopotamicus) and tambacu (Colossoma macropomum $\times$ Piaractus mesopotamicus) juveniles fed two diets, during six months, at cold suboptimal temperature ${ }^{(1)}$.

\begin{tabular}{|c|c|c|c|c|c|}
\hline Source of variation & Final length $(\mathrm{cm})$ & Final weight (g) & DWG (g per day) & Feed efficiency & PER \\
\hline \multicolumn{6}{|l|}{$\mathrm{p}$-value } \\
\hline Interaction $^{(2)}$ & $0.036^{*}$ & $0.036^{*}$ & $0.031^{*}$ & $0.082^{\mathrm{ns}}$ & $0.102^{\text {ns }}$ \\
\hline Genetic group & $0.175^{\text {ns }}$ & $0.005^{*}$ & $<0.001 *$ & $0.005^{*}$ & $0.005^{*}$ \\
\hline Diet & $0.022 *$ & $0.052^{\mathrm{ns}}$ & $0.049^{*}$ & $0.127^{\mathrm{ns}}$ & $0.120^{\mathrm{ns}}$ \\
\hline \multicolumn{6}{|l|}{ Genetic group $^{(3)}$} \\
\hline Pacu & $14.42 \pm 0.69$ & $60.95 \pm 6.92$ & $0.24 \pm 0.04$ & $0.56 \pm 0.09 \mathrm{a}$ & $1.91 \pm 0.31 \mathrm{a}$ \\
\hline Tambacu & $14.21 \pm 0.37$ & $52.85 \pm 3.18$ & $0.18 \pm 0.02$ & $0.43 \pm 0.06 \mathrm{~b}$ & $1.45 \pm 0.19 \mathrm{~b}$ \\
\hline \multicolumn{6}{|l|}{ Diet } \\
\hline Base diet & $14.06 \pm 0.28$ & $54.82 \pm 2.97$ & $0.20 \pm 0.02$ & $0.47 \pm 0.07$ & $1.58 \pm 0.22$ \\
\hline Silage diet & $14.60 \pm 0.61$ & $58.58 \pm 9.20$ & $0.22 \pm 0.06$ & $0.51 \pm 0.13$ & $1.75 \pm 0.45$ \\
\hline
\end{tabular}

${ }^{(1)}$ Means ( \pm standard deviation) of daily maximum and minimum temperatures were $22 \pm 3^{\circ} \mathrm{C}$ and $20 \pm 2^{\circ} \mathrm{C}$, respectively. ${ }^{(2)}$ When interaction was observed, according to the analysis of variance, the factors genetic group and diet were evaluated, combined with the Tukey's test for comparison of means and showed at Figure 1; and when no significant interaction was detected, the factors were evaluated separately by the Tukey's test and shown in the Table 2.

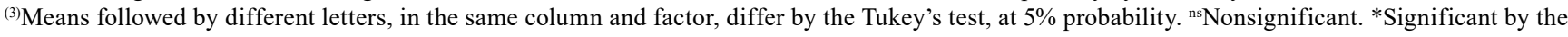
Tukey's test, at $5 \%$ probability. DWG, daily weight gain; PER, protein efficiency rate. 
of mortality, even with the minimum temperature reaching $14^{\circ} \mathrm{C}$. Fish survival was $100 \%$, except for the pacu of base diet treatment, that showed a mean survival of $96 \%$ due to the mortality of a single fish in an experimental unit, thus unrelated to the treatment.

It was also evident the importance of nutrition for the genetic group better adapted to the rearing conditions that showed its potential. The base diet used in the present study was essentially obtained from ingredients of terrestrial origin, like what is found in commercial diets for omnivorous fish. The worldwide use of marine ingredients (such as fish meal and fish oil) has been reduced in fish feeds, but the effects caused by their lack in the diets are not yet fully understood. In this regard, the acid fish silage seemed to be a good substitute, as in the present study it was composed by a mixture of processing residues of fresh water and marine fish. Olsen \& Toppe (2017) described acid fish silage as a food additive rich in hydrolyzed proteins, with beneficial effects on the gut microbiota. In addition, ingredients of marine origin are known as rich sources of long-chain polyunsaturated fatty
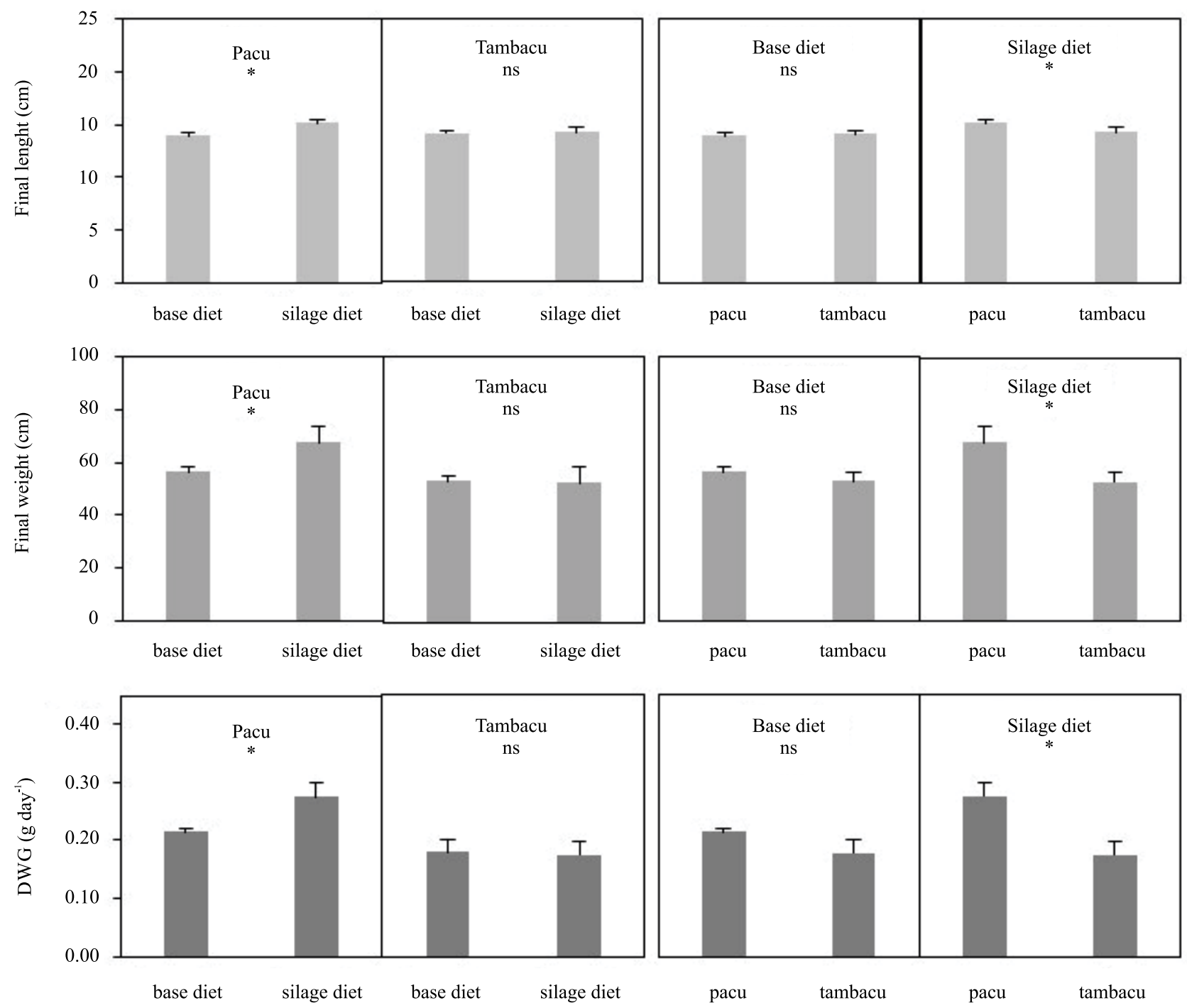

Figure 1. Final length, final weight, and daily weight gain (DWG) of pacu (Piaractus mesopotamicus) and tambacu (Colossoma macropomum $\times$ Piaractus mesopotamicus) juveniles fed two diets, during six months at cold suboptimal temperature. There was interaction, according to the analysis of variance, and the factors "genetic group" and "diet" were evaluated in combination. *Significant at $5 \%$ probability. nsNonsignificant. 
acids (LC-PUFA) of high biologic value, such as DHA and EPA (Tocher, 2015). Guimarães \& Martins (2015) reported that in natural environment, during the dry season, tambaqui ingests zooplankton rich in LCPUFA and, therefore, in rearing conditions, the addition of these fatty acids in the diet will be beneficial. Some studies indicate the importance of these fatty acids in the adaptation of fish to winter (Alhazzaa et al., 2013; Corrêa et al., 2017).

In the present study, no interaction was observed between genetic group and diet for variables other than growth ones. Pacu showed better feed efficiency and protein efficiency rate than tambacu (Table 2). Likewise, the apparent net utilization of protein and energy were higher for pacu (Table 3), which confirms the greater efficiency of this fish in the use of the food for growth. The difference in feed use did not result in differences in the proximal body composition of the fish (Table 4). The addition of fish silage to the diet, differently than expected, did not alter feed use or body composition of the studied genetic groups.

Sandre et al. (2017) studied tambaqui in growth phase $(10$ to $250 \mathrm{~g})$ at $29^{\circ} \mathrm{C}$. The authors observed protein efficiency ratios between 2.88 and 3.32 , which

Table 3. Body indices and retention rate of pacu (Piaractus mesopotamicus) and tambacu (Colossoma macropomum $\times$ Piaractus mesopotamicus) juveniles fed two diets, during six months, at cold suboptimal temperature ${ }^{(1)}$.

\begin{tabular}{|c|c|c|c|c|c|}
\hline Source of variation & ANPU (\%) & ANEU (\%) & Condition factor $(\mathrm{K})$ & VSI (\%) & HSI (\%) \\
\hline \multicolumn{6}{|l|}{$\mathrm{p}$-value } \\
\hline Interaction & $0.358^{\mathrm{ns}}$ & $0.254^{\mathrm{ns}}$ & $0.065^{\text {ns }}$ & $0.465^{\text {ns }}$ & $0.657^{\mathrm{ns}}$ \\
\hline Genetic group & $0.025^{*}$ & $0.001 *$ & $<0.001 *$ & $0.011^{*}$ & $0.412^{\mathrm{ns}}$ \\
\hline Diet & $0.387^{\mathrm{ns}}$ & $0.426^{\mathrm{ns}}$ & $0.015^{*}$ & $0.014 *$ & $0.387^{\mathrm{ns}}$ \\
\hline \multicolumn{6}{|l|}{${\text { Genetic } \text { group }^{(2)}}$} \\
\hline Pacu & $30.06 \pm 4.44 \mathrm{a}$ & $23.84 \pm 2.82 \mathrm{a}$ & $1.98 \pm 0.09 \mathrm{a}$ & $12.02 \pm 1.48 \mathrm{a}$ & $1.35 \pm 0.15$ \\
\hline Tambacu & $23.72 \pm 3.32 \mathrm{~b}$ & $16.13 \pm 2.46 \mathrm{~b}$ & $1.81 \pm 0.04 \mathrm{~b}$ & $10.69 \pm 1.32 b$ & $1.30 \pm 0.17$ \\
\hline \multicolumn{6}{|l|}{ Diet } \\
\hline Base diet & $25.99 \pm 4.49$ & $19.44 \pm 4.22$ & $1.93 \pm 0.12 \mathrm{a}$ & $10.72 \pm 1.33 b$ & $1.29 \pm 0.16$ \\
\hline Silage diet & $27.33 \pm 5.87$ & $19.86 \pm 5.81$ & $1.83 \pm 0.07 \mathrm{~b}$ & $11.98 \pm 1.50 \mathrm{a}$ & $1.35 \pm 0.16$ \\
\hline
\end{tabular}

${ }^{(1)}$ Means ( \pm standard deviation) of daily maximum and minimum temperatures were $22 \pm 3^{\circ} \mathrm{C}$ and $20 \pm 2{ }^{\circ} \mathrm{C}$, respectively. ${ }^{(2)}$ Means followed by different letters, in the same column and factor, differ by the Tukey's test, at $5 \%$ probability. ${ }^{\text {ns }}$ Nonsignificant. *Significant at $5 \%$ probability. ANPU, apparent net protein utilization; ANEU, apparent net energy utilization; VSI, viscerosomatic index; HSI, hepatosomatic index.

Table 4. Body composition (percentage of natural weight) of pacu (Piaractus mesopotamicus) and tambacu (Colossoma macropomum $\times$ Piaractus mesopotamicus) juveniles fed two diets, during six months, at cold suboptimal temperature ${ }^{(1,2)}$.

\begin{tabular}{|c|c|c|c|c|}
\hline Source of variation & Moisture (\%) & Protein $(\%)$ & Lipids (\%) & Ash (\%) \\
\hline \multicolumn{5}{|l|}{ p-value } \\
\hline Genetic group & $0.189^{\text {ns }}$ & $0.769^{\text {ns }}$ & $0.076^{\text {ns }}$ & $0.931^{\mathrm{ns}}$ \\
\hline Diet & $0.254^{\mathrm{ns}}$ & $0.275^{\mathrm{ns}}$ & $0.682^{\mathrm{ns}}$ & $0.406^{\mathrm{ns}}$ \\
\hline Interaction & $0.395^{\text {ns }}$ & $0.248^{\mathrm{ns}}$ & $0.879^{\text {ns }}$ & $0.478^{\text {ns }}$ \\
\hline \multicolumn{5}{|l|}{ Genetic group $^{(3)}$} \\
\hline Pacu & $72.76 \pm 0.71$ & $15.95 \pm 0.76$ & $7.88 \pm 0.25$ & $3.71 \pm 0.20$ \\
\hline Tambacu & $73.73 \pm 1.11$ & $15.98 \pm 0.81$ & $7.02 \pm 0.76$ & $3.70 \pm 0.26$ \\
\hline \multicolumn{5}{|l|}{ Diet } \\
\hline Base diet & $72.95 \pm 1.23$ & $16.18 \pm 0.81$ & $7.53 \pm 0.68$ & $3.76 \pm 0.27$ \\
\hline Silage diet & $73.71 \pm 0.65$ & $15.70 \pm 0.64$ & $7.27 \pm 0.82$ & $3.63 \pm 0.17$ \\
\hline
\end{tabular}

${ }^{(1)}$ Means ( \pm standard deviation) of daily maximum and minimum temperatures were $22 \pm 3^{\circ} \mathrm{C}$ and $20 \pm 2^{\circ} \mathrm{C}$, respectively. ${ }^{(2)}$ Data were evaluated by twoway analysis of variance. ${ }^{(3)}$ Initial composition (percentage of natural weight) of pacu and tambacu juveniles, respectively: moisture, 77.31 and $74.66 \%$; protein, 16.31 and $15.45 \%$; lipids, 2.93 and 6.29 ; ash, 3.97 and $3.60 \%$. ${ }^{\text {ns }}$ Nonsignificant. 
is twice the values obtained in the present study. Also, values of apparent net utilization of protein and energy obtained by the cited authors were $28-36 \%$ for protein and $27-34 \%$ for energy, which are higher than those of the present work, as well as the values of lipids for body composition, which were between 15 and $18 \%$, while in the present study values were near $7 \%$. Pereira et al. (2011) studied tambacu juveniles of approximately $2 \mathrm{~g}$ initial weight and $22 \mathrm{~g}$ final weight, at $24^{\circ} \mathrm{C}$ average temperature; they found daily weight gain between 0.32 and $0.34 \mathrm{~g}$, feed conversion rate between 1.15 and 1.26 (feed efficiency between 0.87 and 0.79 ), these results were better than those of the present study (daily weight gain of 0.18 to 0.28 , and feed efficiency of 0.42 to 0.64 ); however fish accumulated more lipid than protein in the body, inversely to what occurred in the present study. The great differences observed between the present study and the two mentioned studies were probably caused by differences of temperature and, at a minor extent, by other factors as species, diet composition and experimental units. In addition to the expected reduction of food intake, a lower temperature of winter may lead to changes of metabolism. Paula et al. (2014) studied the growth of pacu at three temperatures $\left(24,28\right.$, and $\left.32^{\circ} \mathrm{C}\right)$, and concluded that the lower temperature altered the expression of genes related to muscle, causing a delay of growth.

Regarding diets, differences in digestibility of protein ingredients should not have influenced the growth results in the present work. In studies with pacu, the substitution of fishmeal by soybean meal resulted in a same diet digestibility (Fernandes et al., 2001), or same protein digestibility but lower energy digestibility (Abimorad \& Carneiro, 2004). Despite the differences in the manufacturing of fish silage and fish meal, these ingredients have many similarities. Vidotti et al. (2002) observed $88 \%$ protein digestibility in acid fish silage of marine origin for pacu; the same value was obtained by Abimorad \& Carneiro (2004) with fish meal for the same species.

Studies with tambaqui and pacu indicate that they are well adapted to plant sources of protein in the diet. Both for tambaqui (Van Der Meer et al., 1996) and pacu (Fernandes et al., 2001) the authors observed that fish meal can be completely replaced by soybean meal, as protein source of the diet, without loss of growth, or food use; however, these two studies were performed at optimum temperature; moreover, all diets were supplemented with fish oil in the study with tambaqui, and the origin of fish meal was not described in the study with pacu, which hinders evaluation of results. In the present study, acid fish silage was important to supply the necessary nutrients to improve the growth of pacu juvenile, but the silage had no influence on the diet use by fish, or on the proximal body composition of fish.

Additionally, a higher condition factor was observed for pacu than that of tambacu (Table 3), and for fish fed the base diet than for those fed the silage diet. This result seems contradictory, since pacu fed the silage diet showed a better growth than fish of the other treatments. However, condition factor is a relationship between the weight and the length of fish, which indicates that the genetic group pacu had a stronger influence on weight gain, whereas the silage diet had more influence on length growth. The viscerosomatic index was higher for pacu than tambacu in the present study, with the use of the silage diet instead of the base diet, which correlates with the higher growth, but not with the body fat content. There was no difference for hepatosomatic index between the treatments, which indicates the similar health conditions of fish of different treatments.

\section{Conclusions}

1. Pacu shows a better growth than tambacu only when the diet of plant origin is supplemented with acid fish silage, under rearing conditions at cold suboptimal temperature.

2. Pacu shows a better food use than tambacu, irrespectively of the supplementation of acid fish silage in the diet, in rearing conditions at cold suboptimal temperature.

\section{References}

ABIMORAD, E.G.; CARNEIRO, D.J. Métodos de coleta de fezes e determinação dos coeficientes de digestibilidade da fração protéica e da energia de alimentos para o pacu, Piaractus mesopotamicus (Holmberg, 1887). Revista Brasileira de Zootecnia, v.33, p. 1101-1109, 2004. DOI: https://doi.org/10.1590/ S1516-35982004000500001.

ALHAZZAA, R.; BRIDLE, A.R.; NICHOLS, P.D.; CARTER, C.G. Coping with sub-optimal water temperature: modifications in fatty acid profile of barramundi as influenced by dietary lipid. Comparative Biochemistry and Physiology, Part A, v.165, p.243-253, 2013. DOI: https://doi.org/10.1016/j.cbpa.2013.03.019. 
AOAC. Official Methods of Analysis of the AOAC International. $17^{\text {th }}$ ed. Gaithersburg, 1999. Methods: crude protein (Kjeldahl, method 945.01), lipid (Soxthlet, method 920.39), mineral matter (muffle at $550^{\circ} \mathrm{C}$, method 942.05 ) and moisture $\left(105^{\circ} \mathrm{C}\right.$ to constant weight, method 950.01).

BANZE, J.F.; SILVA, M.F.O. da; ENKE, D.B.S.; FRACALOSSI, D.M. Acid silage of tuna viscera: production, composition, quality and digestibility. Boletim do Instituto de Pesca, v.44, p.24-34, 2017. Volume especial. DOI: https://doi.org/10.20950/16782305.2017.24.34.

BICUDO, A.J.A.; ABIMORAD, E.G.; CARNEIRO, D.J. Exigências nutricionais e alimentação do pacu. In: FRACALOSSI, D.M.; CYRINO, J.E.P. (Ed.). Nutriaqua: Nutrição e alimentação de espécies de interesse para a aquicultura brasileira. Florianópolis: Sociedade Brasileira de Aquicultura e Biologia Aquática, 2012, p.217-229.

CORREAA, C.F.; NOBREGA, R.O.; MATTIONI, B.; BLOCK, J.M.; FRACALOSSI, D.M. Dietary lipid sources affect the performance of Nile tilapia at optimal and cold, suboptimal temperatures. Aquaculture Nutrition, v.23, p.1016-1026, 2017. DOI: https://doi.org/10.1111/anu.12469.

EL-SAYED, A.-F.M. Alternative dietary protein sources for farmed tilapia, Oreochromis spp. Aquaculture, v.179, p.149-168, 1999. DOI: https://doi.org/10.1016/S0044-8486(99)00159-3.

FAO. Food and Agriculture Organization of United Nations. The State of World Fisheries and Aquaculture 2018: Meeting the sustainable development goals. Rome, 2018. 210p.

FERNANDES, E.M.; ALMEIDA, L.C.F. de; HASHIMOTO, D.T.; LATTANZI, G.R.; GERVAZ, W.R.; LEONARDO, A.F.; REIS NETO, R.V. Survival of purebred and hybrid Serrasalmidae under low water temperature conditions. Aquaculture, v.497, p.97-102, 2018. DOI: https://doi.org/10.1016/j.aquaculture.2018.07.030.

FERNANDES, J.B.K.; CARNEIRO, D.J.; SAKOMURA, N.K. Fontes e níveis de proteína bruta em dietas para juvenis de pacu (Piaractus mesopotamicus). Revista Brasileira de Zootecnia, v.30, p.617-626, 2001. DOI: https://doi.org/10.1590/S151635982001000300003.

GUIMARÃES, I.G.; MARTINS, G.P. Nutritional requirement of two Amazonian aquacultured fish species, Colossoma macropomum (Cuvier, 1816) and Piaractus brachypomus (Cuvier, 1818): a mini review. Journal of Applied Ichthyology, v.31, p.5766, 2015. Supplement 4. DOI: https://doi.org/10.1111/jai.12976.

IBGE. Instituto Brasileiro de Geografia e Estatística. Produção da Pecuária Municipal 2016. Rio de Janeiro: IBGE, v.44, 2016. 49p.

LEONARDO, A.F.; CORRÊA, C.F.; BACCARIN, A.E. Qualidade da água de um reservatório submetido à criação de tilápias em tanques-rede, no sul de São Paulo, Brasil. Boletim do Instituto de Pesca, v.37, p.341-354, 2011.

OLIVEIRA, A.C.B. de; MIRANDA, E.C. de; CORREA, R. de $O$. Exigências nutricionais e alimentação do tambaqui. In:
FRACALOSSI, D.M.; CYRINO, J.E.P. (Ed.). Nutriaqua: nutrição e alimentação de espécies de interesse para a aquicultura brasileira. Florianópolis: Sociedade Brasileira de Aquicultura e Biologia Aquática, 2012. p.231-240.

OLSEN, R.L.; TOPPE, J. Fish silage hydrolysates: not only a feed nutrient, but also a useful feed additive. Trends in Food Science \& Technology, v.66, p.93-97, 2017. DOI: https://doi.org/10.1016/j. tifs.2017.06.003.

PAULA, T.G. de; ALMEIDA, F.L.A. de; CARANI, F.R.; VECHETTI-JÚNIOR, I.J.; PADOVANI, C.R.; SALOMÃO, R.A.S.; MARECO, E.A.; SANTOS, V.B. dos; DAL-PAI-SILVA, $M$. Rearing temperature induces changes in muscle growth and gene expression in juvenile pacu (Piaractus mesopotamicus). Comparative Biochemistry and Physiology, Part B, v.169, p.3137, 2014. DOI: https://doi.org/10.1016/j.cbpb.2013.12.004.

PEREIRA, M.C.; AZEVEDO, R.V. de; BRAGA, L.G.T. Óleos vegetais em rações para o híbrido tambacu (macho Piaractus mesopotamicus x fêmea Colossoma macropomum). Revista Brasileira de Saúde e Produção Animal, v.12, p.551-562, 2011.

PEZZATO, L.E.; BARROS, M.M.; FURUYA, W.M. Valor nutritivo dos alimentos utilizados na formulação de rações para peixes tropicais. Revista Brasileira de Zootecnia, v.38, p.43-51, 2009. Suplemento especial. DOI: https://doi.org/10.1590/S151635982009001300005.

REIS NETO, R.V.; SERAFINI, M.A.; FREITAS, R.T.F. de; ALLAMAN, I.B.; MOURAD, N.M.N.; LAGO, A. de A. Performance and carcass traits in the diallel crossing of pacu and tambaqui. Revista Brasileira de Zootecnia, v.41, p.2390-2395, 2012. DOI: https://doi.org/10.1590/S1516-35982012001200002.

SANDRE, L.C.G.; BUZOLLO, H.; NASCIMENTO, T.M.T.; NEIRA, L.M.; JOMORI, R.K.; CARNEIRO, D.J. Productive performance and digestibility in the initial growth phase of tambaqui (Colossoma macropomum) fed diets with different carbohydrate and lipid levels. Aquaculture Reports, v.6, p.28-34, 2017. DOI: https://doi.org/10.1016/j.aqrep.2017.02.003.

TOCHER, D.R. Omega-3 long-chain polyunsaturated fatty acids and aquaculture in perspective. Aquaculture, v.449, p.94-107, 2015. DOI: https://doi.org/10.1016/j.aquaculture.2015.01.010.

VAN DER MEER, M.B.; HUISMAN, E.A.; VERDEGEM, M.C.J. Feed consumption, growth and protein utilization of Colossoma macropomum (Cuvier) at different dietary fish meal/ soya meal ratios. Aquaculture Research, v.27, p.531-538, 1996. DOI: https://doi.org/10.1111/j.1365-2109.1996.tb01283.x.

VIDOTTI, R.M.; CARNEIRO, D.J.; VIEGAS, E.M.M. Acid and fermented silage characterization and determination of apparent digestibility coefficient of crude protein for pacu Piaractus mesopotamicus. Journal of the World Aquaculture Society, v.33, p.57-62, 2002. DOI: https://doi.org/10.1111/j.1749-7345.2002. tb00478.x. 